\title{
COMPUTATIONAL STUDIES OF SOME BENZOTHIAZINONE- PEPIRAZINE DERIVATIVES AND LIPASE B INHIBITOR FOR MYCOBACTERIUM TUBERCULOSIS
}

\author{
Y. Y. Muhammad ${ }^{1, *}$, A. Uzairu ${ }^{2}$ \\ ${ }^{1}$ Kano University of Science and Technology, Department of Chemistry, Wudil, Kano, Nigeria \\ ${ }^{2}$ Ahmadu Bello University, Faculty of Science, Department of Chemistry, Zaria, Nigeria
}

${ }^{*}$ Corresponding author. Kano University of Science and Technology, Department of Chemistry, Wudil, Kano, Nigeria, Phone: +2347030929397

e-mail address: yakubuyaum@gmail.com (Y.Y. Muhammad).

\section{A R T I C L E I N F O}

Article history:

Received 2020-10-01

Accepted 2020-10-20

Available online 2020-10-20

keywords

Molecular docking

QSAR modelling

Binding affinity

Anti-tuberculosis
A B S T R A C T

Computational technique was employed on Benzothiazinone-pepirazine derivatives as dominant anti-mycobacterium tuberculosis. The compound structures were drawn with the aid of chemdraw 3D Pro 12.1.0V and optimized was employed using DFT method applying B3LYP with the 6-31G/ basis set. Genetic Function Approximation (GFA) was employed to form five models. Model 1 was sorted out based on model validation parameters and found to be significant with $R^{2}$ value of $0.948605, R_{\text {adj }}^{2}$ (adjusted correlation coefficient) value of 0.934329, $Q_{\text {Loo }}$ (Cross validation coefficient) value 0.892724 and $R^{2}$ pred value of 0.658537 . The docking studies showed that the ligand 6, 7 and 18 has the highest binding affinities of $10.5,10.4,10.3 \mathrm{k} /$ mole are the most vital compounds among the binding scores. Ligand 6 being among the ligands with the highest binding affinity $(-10.5 \mathrm{k} / \mathrm{mole})$ was found to be more potent than other compounds. Stability and Robustness the model highlight the way for designing latest Benzothiazinone-pepirazine analogue with better activity against mycobacterium tuberculosis. 


\section{INTRODUCTION}

Tuberculosis (TB) is a lung disorder caused primarily due to Mycobacterium tuberculosis and is one of the most dangerous infectious disease in the universe. In line with the World Health Organization (WHO) estimates TB kills more adults now than all other infectious diseases (WHO, 2015). In 2017, (WHO) rated 1.3 million deaths (range, 1.2-1.4 million) among HIV-negative people and there were an additional 300000 deaths from TB (range, 266 000-335 000) among HIV-positive people. 5.8 million Men, 3.2 million women and 1.0 million children, developed TB disease in 2017, ranging from 9.0-11.1 million people globally (WHO, 2018). Rifampicin, isoniazid ciprofloxacin, and ethambutol are drugs available for treatment of tuberculosis. The development of multidrug resistant (MDR) and extensively drug resistant (XDR) tuberculosis withstand current drugs and this bestow a serious summons towards successful therapy of tuberculosis (Lemichnane et al., 2011).

Meanwhile, the first-line TB drugs presently utilize are at least 40 years old with an increase in drug-resistant strains of myco-bacterium tuberculosis. Similarly, the second-line drugs cast-off mostly for the curing of multidrug-resistant and extensively drug-resistant (XDR) TB incite serious side effects according to WHO (WHO, 20104). To tackle the mycobacterial resistance, there is a demand to recognize novel targets special to tuberculosis which are vague in humans whose hindrance would either prove mortal to the bacterium or render it tremendously to the host immune reaction (Prakash et al., 2005). The high resistances of the M. tuberculosis toward the current drugs led to the progress of QSAR method that is easy, quick and precise to forecast the experimental activities for the latest molecules facing M. tuberculosis (Shola et al., 2019). Computational technique has guide to the assessment of current medication with a less side effect and high therapeutic ability (Abdulfatai et al., 2017).

QSAR modelling alongside with molecular docking approaches were applied to forecast the activities of various inhibitor compounds and interpret the regions of association (steric, hydrogen bond distance, hydrophobic, and hydrogen bond etc) may reduce or escalate the activities (Shola et al., 2018). The investigation was aimed to developed QSAR model and to anticipate the activity of Benzothiazinonepiperazine derivatives with strong anti-tuberculosis means and to performed docking technique between the ligand and the Lipase B enzyme.

\section{MATERIALS AND METHOD}

\subsection{Source of Dataset}

Thirty-five molecules of Benzothiazinone-piperazine derivatives as dominant anti-tuberculosis agents were retrieved from the literature (Manoj et al., 2015) and applied in this research. The experimental activity $\left(\mathrm{IC}_{50}\right)$ expressed in $\mu \mathrm{M}$ were converted to $\left.\mathrm{pIC}_{50}\left[=-\log \mathrm{IC}_{50} \times 10^{6}\right]\right)$ to minimize data distribution and enhanced the linearity of the activity values. The two-dimensional structure (2D) and biological activities of Mycobacterium-tuberculosis used in this study are presented in Table 1 (See Supplementary Information).

\subsection{Numerical and Computational Procedures}

The 2D structure of each molecules were drawn with aid of chemdraw 3D Pro 12.0.1 V (Becke, 1993). Optimization was taken place using Spartan' 14 V1.1.0 on Hp computer system, using DFT (Density Functional Theory level) with B3LYP (Becke's three-parameter Lee-Yang-Parr hybrid functional) and also in merger with the 6-31G* basis set (Yap, 2011). B3LYP/6-311G* basis set is choose due to the fact that it gives a better result. The paDEL descriptor toolkit was employed to give the molecular descriptors of the optimized compounds. The data sets of the molecules were divided into 26 molecules for developing the model and 7 molecules for model external validation.

The models were generated by applying the GFA (Genetic Function Approximation) method inserted in Material Studio, (a simulation and modelling) software utilize the experimental activities as the dependent variable while the computed descriptors as independent variables.

Five models were inscribed out and model 1 was sort out as the top for anticipating $\mathrm{pIC}_{50}$ of anti- tuberculosis compounds due to it physicochemical parameter. The built QSAR model, was appraised by the external prognostic ability and extrapolation of the best model using the molecules of test set with the aid of equation.

$$
\mathrm{R}_{\text {pred }}^{2}=1-\left[\frac{\sum(\text { Ypred-Yexp })^{2}}{\sum\left({\text { Ypred-Ytrain })^{2}}^{2}\right.}\right]
$$

Where $\mathrm{Y}_{\text {test(tpred) }}$ and $\mathrm{Y}_{\text {test(exp) }}$ are the predicted and experimental activity of the test sets respectively and $Y_{\text {train }}$ is the test set mean activity value (Muhammad et al., 2018).

\subsection{Model Applicability Domain}

The model applicability domain is utilized to dictate the influential and outliers' molecules of the QSAR model certify the robustness and reliability of the developed model. Evaluation of QSAR model is the predominant technique to verify that the model generate is qualified to build better forecast within the chemical area for which it was generated (Tropsha et al; 2003). The leverage (hii) of a given compound can be calculated in the equation given below:

$$
h_{i i}=x_{i}^{T}\left(X^{T} X\right)^{-1} x_{i}
$$

Where $h i$ is the leverage of each molecule, $x i$ is the descriptor row matrix of the molecule under consideration and $X$ is the calculated molecular descriptors for each training set compound. The warning leverage $(h *)$ is the limit of normal values for $X$ outliers and is defined as:

$$
h^{*}=\frac{3(y+1)}{n}
$$

Where $\mathrm{n}$ is the total number of training molecules and $\mathrm{y}$ is the number of molecular descriptors in the model. The Williams plot was applied to explain the importance region of the model in terms of chemical space. The compound is 
said to be an outlier if the leverages value is outside domain.

\subsection{Y-Randomization Test}

To be guaranteed that the QSAR model generated is well built, the $\mathrm{Y}$ - randomization test was executed on the training test data. The lower values of $\mathrm{R}^{2}$ and $\mathrm{Q}^{2}$ of the newly developed QSAR models for numerous trials certify that the models are authentic. $\mathrm{CR}_{\mathrm{p}}^{2}$ is another determination factor for Y-randomization calculated, which should be greater than 0.5 for passing this test.

$$
c R_{p=R}^{2} R *\left[R^{2}-\left(R_{r}^{2}\right)\right]^{2}
$$

\section{RESULTS AND DISCUSSION}

Model 1 was selected among the five generated QSAR

\subsection{QSAR Result}

Best model equation

$$
\begin{array}{rl}
p I C_{50}=-4.4679 & 9290 * \text { AATS3e }+4.343967313 \\
& * \text { GATS6m }+6.138836616 * \mathbf{I C 0} \\
& -0.029770404 *\left(\mathbf{S p D i a m}_{\mathbf{D t}}-507.60\right) \\
& +0.005367093 *(707.04-\mathbf{A T S} 2 \mathbf{e}) \\
& +24.49962
\end{array}
$$

The model descriptors, classes and their definition are present in table 3. An increase in GATS6m (Geary autocorrelation-lag6/weighted by mass), IC0 Information content index (neighbourhood symmetry of 0-order) and ATS2e (Broto-Moreau autocorrelation-lag 2/weighted by senderson electronegativities) descriptors in the model 1 will definitely increase the anti- tuberculosis activities of Benzothiazinone derivatives against lipase B enzyme. Moreover, decrease in descriptors with negative coefficient such as AATS3e (Average centered Broto-Moreau autocorrelation - lag 3/weighted by

\subsection{Molecular Docking Studies}

Initially the optimized molecules were retained as SDF files which transformed to PDB files using Spartan 14 software Version 1.1.4. Lipase B structure employed in this research was recaptured from protein data bank. Docking technique was performed between Lipase B enzyme and Benzothiazinone derivatives using AutoDock vina of PyRx virtual screening software (Trott and Olson 2010). Discovery Studio Visualizer was employed to visualize the docking interaction between the prepared receptor (lipase B) with prepared ligand.

model for predicting the activity $\left(\mathrm{pIC}_{50}\right)$ of anti- tuberculosis compounds due to it physicochemical parameter. The model validation parameters (internal and external) was proceed through the minimum standard QSAR model shown in Table 2.

$\mathrm{R}_{\text {trng }}^{2}=0.948605, \mathrm{R}_{\text {adj }}^{2}=0.934329, \mathrm{Q}^{2} \mathrm{LOO}=0.892724, \mathrm{~N}_{\text {trng }}=26$,

$\mathrm{N}_{\text {test }}=9, \mathrm{R}_{\text {test }}^{2}=0.658537$

Min expt. error for non-significant $\operatorname{LOF}(95 \%)=0.068823$

sanderson electronegativities) and SpDiam_Dt (Spectral diameter from detour matrix) will undoubtedly increase the hydrophobicity and binding ability of the inhabitors.

Figure 1 present the graph of predicted activities against experimental activities of both the training and test sets. The

\begin{tabular}{|c|c|c|c|}
\hline $\mathbf{S} / \mathbf{N}$ & Descriptors & Definition & Classes \\
\hline 1 & AATS3e & $\begin{array}{l}\text { Average centered Broto-Moreau autocorrelation - lag } 3 \\
\text { /weighted by sanderson electronegativities }\end{array}$ & $2 \mathrm{D}$ \\
\hline & GATS6m & Geary autocorrelation- lag 6/weighted by mass & 2D \\
\hline 3 & ICO & $\begin{array}{l}\text { Information content index (neighbourhood symmetry of } \\
0 \text {-order) }\end{array}$ & $2 \mathrm{D}$ \\
\hline 4 & SpDiam_Dt & Spectral diameter from detour matrix & 2D \\
\hline 5 & ATS2e & $\begin{array}{l}\text { Broto-Moreau autocorrelation - lag 3/weighted by } \\
\text { sanderson electronegativities }\end{array}$ & $2 \mathrm{D}$ \\
\hline
\end{tabular}
accuracy of the model indicates the high linearity of the plot which confirmed its high prognostic power of the model. Moreover, the external validation and predictive $\mathrm{R}^{2}$ value of the model were calculated and present in Table $3 \mathrm{~A}$ and $3 \mathrm{~B}$.

Table 2 - Molecular descriptors, their definition and classes of model (Todeschini et al; 2009). 


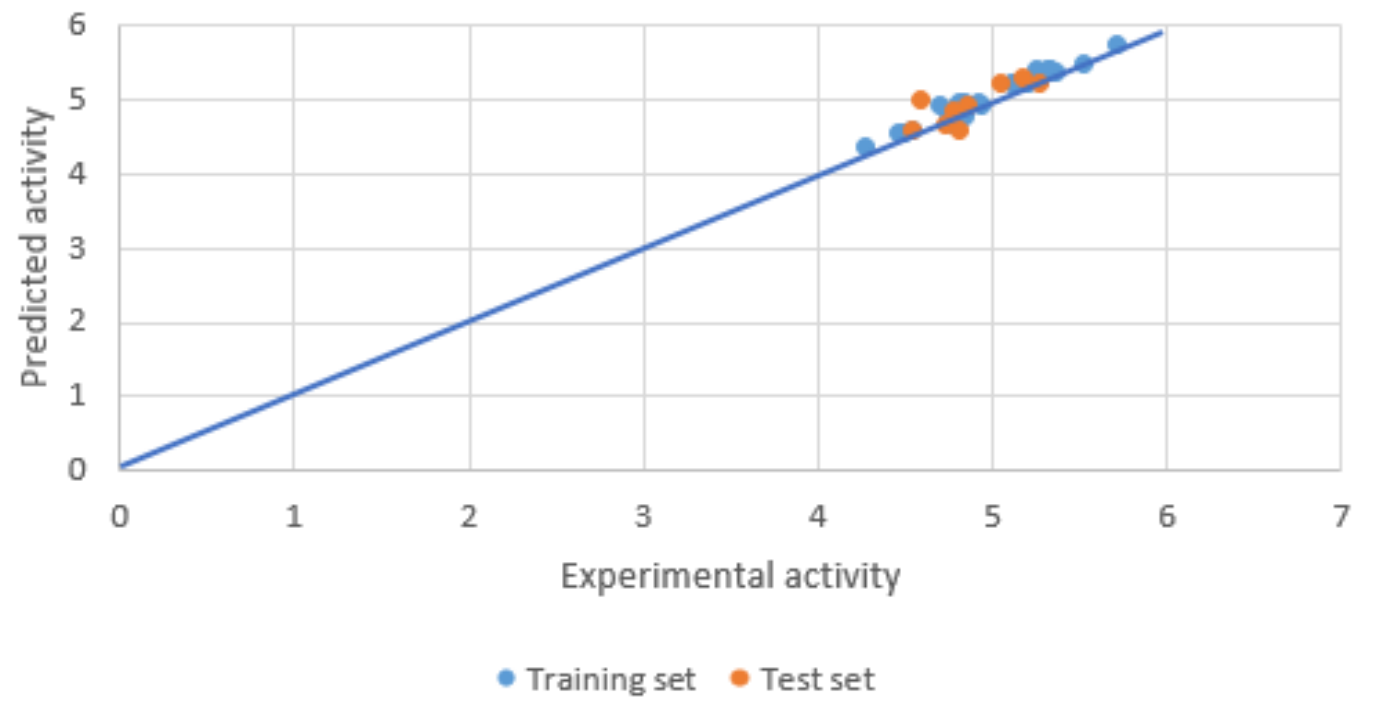

Figure 1 - The graph of the biological versus Predicted activity of both the training and test sets of model

Table 3A - External validation of the model 1

\begin{tabular}{|r|r|r|r|r|l|l|}
\hline AATS3e & \multicolumn{1}{|l}{ GATS6m } & \multicolumn{1}{l}{ IC0 } & \multicolumn{1}{l}{ SpDiam_Dt } & \multicolumn{1}{l}{ ATS2e } & \multicolumn{1}{l}{ Ypred } & \multicolumn{1}{l|}{ pIC50 } \\
\hline 7.923033 & 0.8877 & 1.651382 & 465.5386 & 669.3793 & 4.547641 & 4.55 \\
\hline 7.968921 & 0.935414 & 1.839835 & 484.946 & 714.4514 & 4.887088 & 4.87 \\
\hline 7.871679 & 0.756033 & 1.497827 & 425.1277 & 637.5031 & 4.636609 & 4.74 \\
\hline 7.923033 & 0.779252 & 1.851382 & 469.2473 & 669.3793 & 5.193908 & 5.28 \\
\hline 7.921361 & 0.796498 & 1.939835 & 484.946 & 702.8814 & 5.172122 & 5.06 \\
\hline 7.819505 & 0.530337 & 1.597827 & 425.1277 & 625.933 & 4.565291 & 4.83 \\
\hline 7.753038 & 0.452565 & 1.670689 & 425.3415 & 657.8819 & 4.79388 & 4.8 \\
\hline 7.801962 & 0.56632 & 1.827144 & 443.5349 & 702.954 & 5.24636 & 5.19 \\
\hline 7.594835 & 0.227875 & 1.561996 & 387.4915 & 663.5103 & 4.954039 & 4.61 \\
\hline
\end{tabular}

Table 3B - Assessment of the predictive R2 of model 1.

\begin{tabular}{|c|c|c|c|c|}
\hline $\mathbf{Y}_{\text {pred }}-\mathbf{Y}_{\text {exp }}$ & $\left(\mathbf{Y}_{\text {pred }}-\mathbf{Y}_{\text {exp }}\right)^{2}$ & $\mathbf{Y}_{\text {trng }}$ & $\left(\mathbf{Y}_{\text {exp }}-\mathbf{Y}_{\text {trng }}\right)$ & $\left(\mathbf{Y}_{\text {exp }}-\mathbf{Y}_{\text {trng }}\right)^{2}$ \\
\hline 0.002359 & $5.56418 \mathrm{E}-06$ & 5.01153 & -0.46153 & 0.21301 \\
-0.01709 & 0.000292012 & 5.01153 & -0.14153 & 0.020031 \\
0.103391 & 0.010689598 & 5.01153 & -0.27153 & 0.073729 \\
0.086092 & 0.007411748 & 5.01153 & 0.26847 & 0.072076 \\
-0.11212 & 0.012571252 & 5.01153 & 0.04847 & 0.002349 \\
0.264709 & 0.070070855 & 5.01153 & -0.18153 & 0.032953 \\
0.00612 & $3.7452 \mathrm{E}-05$ & 5.01153 & -0.21153 & 0.044745 \\
-0.05636 & 0.00317647 & 5.01153 & 0.17847 & 0.031852 \\
-0.34404 & 0.118363107 & 5.01153 & -0.40153 & 0.161226 \\
\hline & $\Sigma\left(\mathbf{Y}_{\text {pred }}-\mathbf{Y}_{\exp }\right)^{2}=0.2226$ & & \\
& & $\mathrm{R}^{2}=(1-0.2226 / 0.6519)=0.65853$ & \\
\end{tabular}


Table 5 - Y randomization test result

\begin{tabular}{|c|c|c|c|}
\hline Model & $\mathbf{R}$ & $\mathbf{R}^{\wedge} 2$ & $Q^{\wedge} 2$ \\
\hline Original & 0.985622 & 0.97145 & 0.828461 \\
\hline Random 1 & 0.982428 & 0.965164 & 0.828164 \\
\hline Random 2 & 0.781438 & 0.610646 & -1.3712 \\
\hline Random 3 & 0.756959 & 0.572986 & -0.93703 \\
\hline Random 4 & 0.372437 & 0.13871 & -3.84808 \\
\hline Random 5 & 0.473695 & 0.224387 & -2.92478 \\
\hline Random 6 & 0.799852 & 0.639763 & -0.84577 \\
\hline Random 7 & 0.920143 & 0.846664 & -0.40989 \\
\hline Random 8 & 0.699882 & 0.489835 & -2.75574 \\
\hline Random 9 & 0.445727 & 0.198672 & -1.89996 \\
\hline Random 10 & 0.963859 & 0.929024 & 0.566911 \\
\hline \multicolumn{4}{|c|}{ Random Models Parameters } \\
\hline Average $r$ : & \multicolumn{3}{|c|}{0.719642} \\
\hline Average $r^{\wedge} 2$ & \multicolumn{3}{|c|}{0.561585} \\
\hline Average $Q^{\wedge} 2$ : & \multicolumn{3}{|c|}{-1.35974} \\
\hline $\mathrm{cRp}^{\wedge} 2$ & \multicolumn{3}{|c|}{0.663789} \\
\hline
\end{tabular}

Meanwhile, Figure 2 present the Williams plot (standardized residual against leverages). From the plot only one compound is discovered to be an outlier compound which is part of the test set. This compound has the leverages value high than the warning leverages $\left(h^{*}=0.69\right)$ is attribute because the compound structure is different from other compounds in the dataset. The Y- randomization test was presented in table 6. The minimal values of $\mathrm{R}^{2}$ and $\mathrm{Q}^{2}$ for the numerous trials confirm that the generated QSAR model is reliable and steady. Moreover, the $\mathrm{CR}_{\mathrm{p}}^{2}$ value greater than 0.5 guaranteed that the developed models is well built.

\subsection{Molecular Docking Result of Benzothiazinone-} piperazine Derivatives

Docking technique of Benzothiazinone-piperazine derivatives was performed against lipase $\mathrm{B}$ (receptor) to find out their interactions and their docking affinities. Compounds with best docking scores are shown in table 6 . The docking study revealed clearly that the ligand number 6 has the highest binding score $(-10.5) \mathrm{kcal} / \mathrm{mole}$ and formed hydrogen

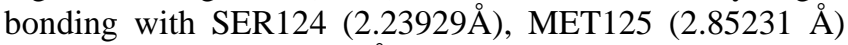
and TRP262 (2.24581 $\AA$ ) and is also surrounded by hydrophobic residues such as LEU40, PHE150, TRP262, ARG41, LEU161, ILE162, TRO158, ALA165, LEU227, ALA165 and LEU227, electrostatic interaction with LEU161. This computational study disclosed that ligand number 6 showed good binding affinity toward the Lipase B enzymes than another co-ligand. Figure 3 shows the ligand 6 and 7,3D and 2D structure of respectively.

Table 6 - Binding energy, Interaction residues, Hydrogen bonds and Hydrogen bond distance of ligand with highest docking scores

\begin{tabular}{|c|c|c|c|c|c|}
\hline Ligand & $\begin{array}{l}\text { Binding } \\
\text { Energy }\end{array}$ & Hydrophobic Interaction & $\begin{array}{l}\text { Electrostatic/ } \\
\text { Other } \\
\text { Interaction }\end{array}$ & $\begin{array}{l}\text { Hydrogen } \\
\text { Bond }\end{array}$ & $\begin{array}{l}\text { Hydrogen Bond } \\
\text { Distance }\end{array}$ \\
\hline 6 & -10.5 & $\begin{array}{l}\text { LEU40,PHE150,TRP262,A } \\
\text { RG41,LEU161,ILE162, } \\
\text { PHE150,TRP158,ALA165,L } \\
\text { EU227,ALA165, and } \\
\text { LEU227 }\end{array}$ & LEU161 & $\begin{array}{l}\text { SER124,MET } \\
\text { 125,TRP262 }\end{array}$ & $\begin{array}{l}2.23929 \\
2.86942 \\
2.24581\end{array}$ \\
\hline 7 & -10.4 & $\begin{array}{l}\text { LEU40,PHE150,TRP262,A } \\
\text { RG41,LEU161,ILE162,PHE } \\
\text { 150,TRP158,ALA165,LEU2 } \\
\text { 27,ALA165,LEU227 }\end{array}$ & LEU161 & $\begin{array}{l}\text { SER124,MET } \\
\text { 125,TRP262 }\end{array}$ & $\begin{array}{l}2.0823 \\
2.71691 \\
1.98299\end{array}$ \\
\hline 18 & -10.3 & $\begin{array}{l}\text { LEU40,PHE150,ARG41,AL } \\
\text { A165,ILE162,ILE51,PHE15 } \\
\text { 0,ALA165,LEU227,LEU40, } \\
\text { ALA165,LEU227,ARG41 }\end{array}$ & $\begin{array}{l}\text { LEU161,TRP } \\
262\end{array}$ & $\begin{array}{l}\text { SER124,MET } \\
\text { 125,TRP262 }\end{array}$ & $\begin{array}{l}1.91458 \\
2.54996 \\
3.02782\end{array}$ \\
\hline
\end{tabular}




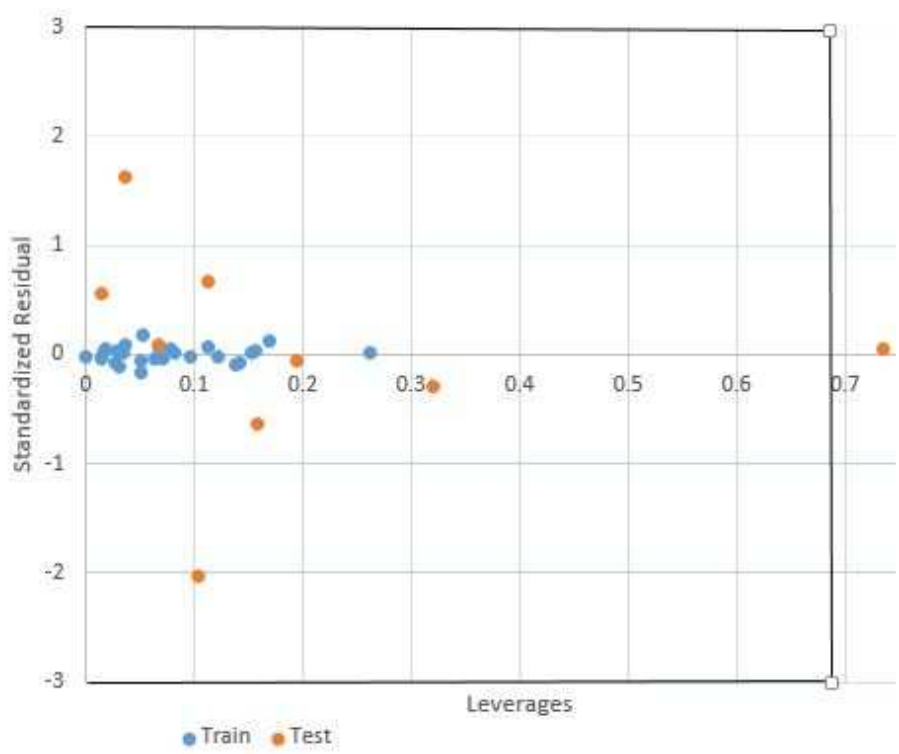

Figure 2 - Williams plot of the best model
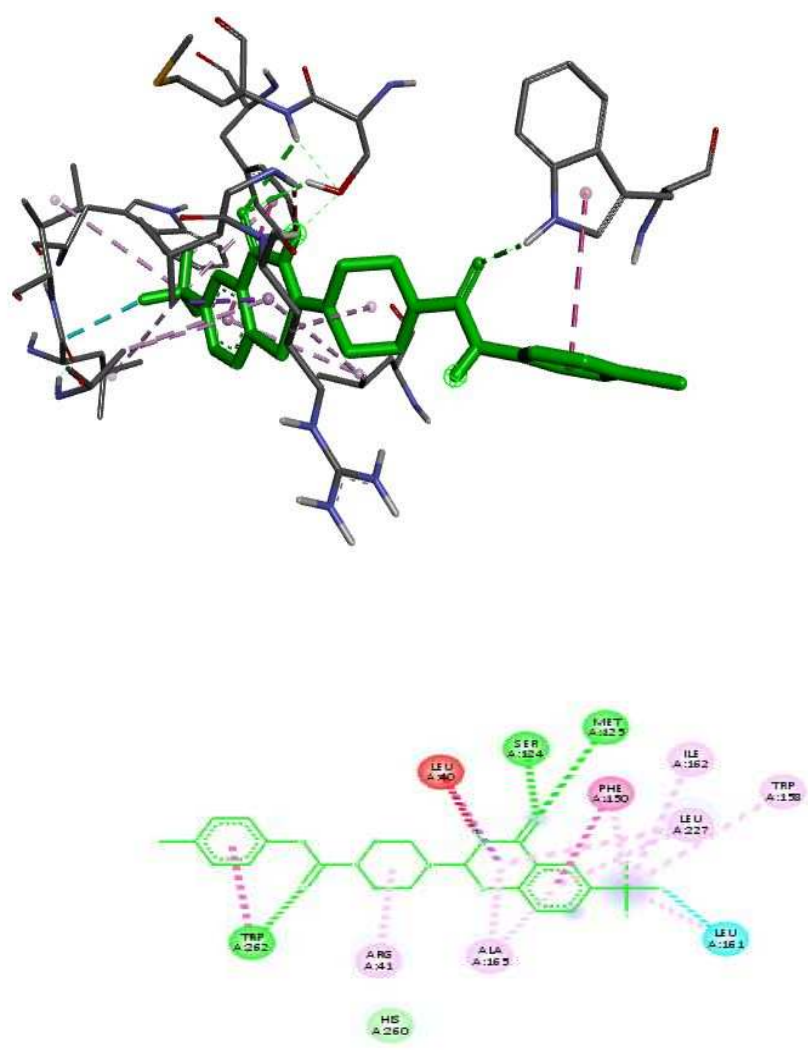

Interactions
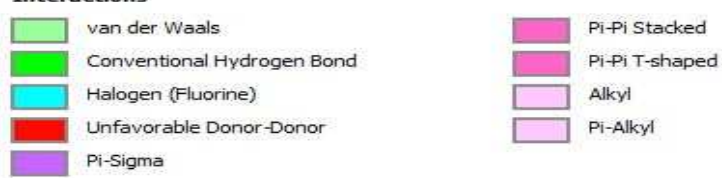

Figure 3A-3D and 2D interaction diagrams of predicted complexes of Lipase B with compound 6
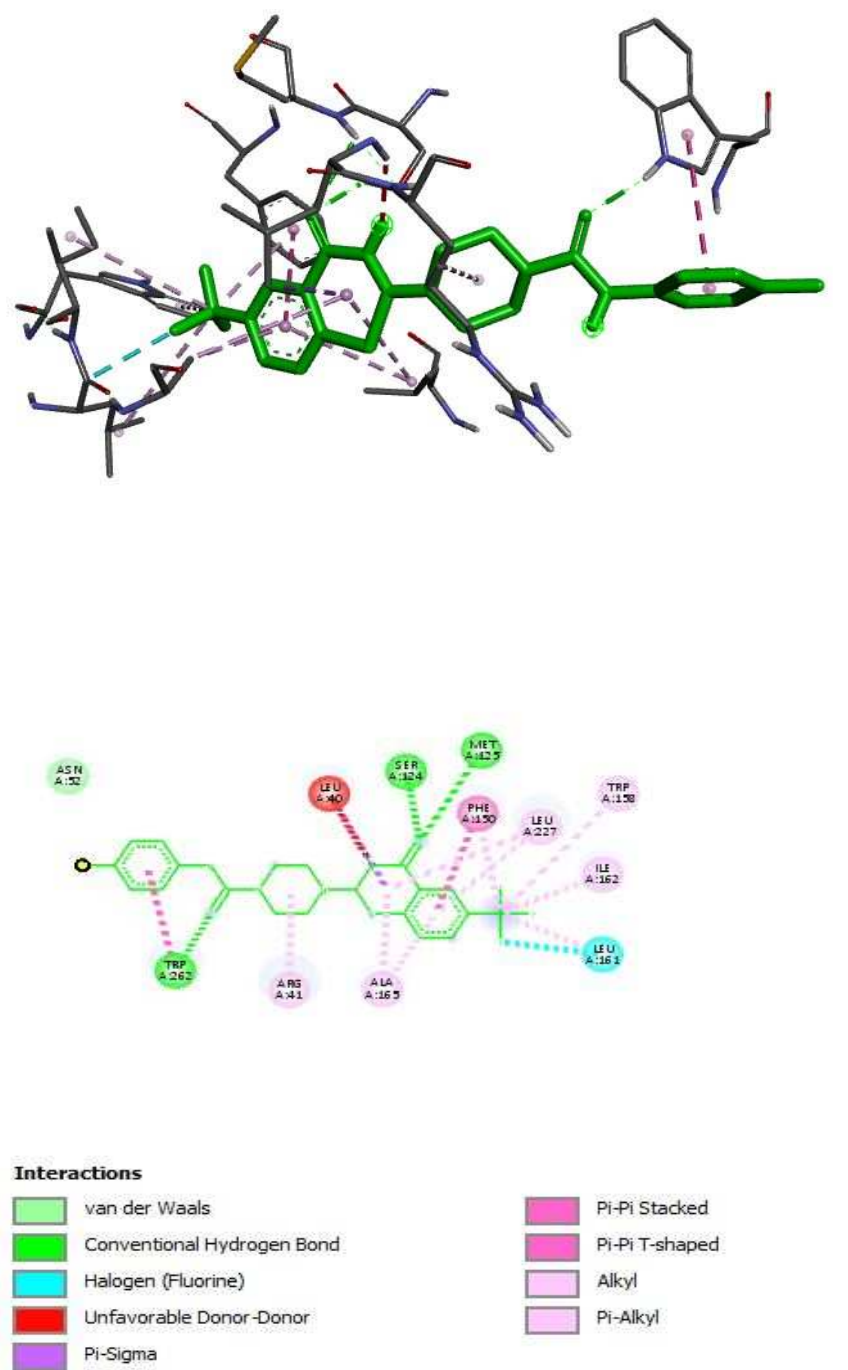

Pi-Pi Stacked

Pi-Pi T-shaped

Alkyl

Pi-Alkyl

Figure 3B- 3D and 2D interaction diagrams of predicted complexes of Lipase B with compound 7 


\section{CONCLUSION}

An insilico method was performed on 35 Benzothiazinone-piperazine derivatives as anti-tuberculosis molecules. The Model was evaluated internally and externally due to it physicochemical parameter of square correlation coefficient $\left(\mathrm{R}^{2}\right)$ of 0.948605 , adjusted squared correlation coefficient $\left(\mathrm{R}^{2}\right.$ adj $)$ value of 0.934329 , Leave one out (LOO) cross-validation coefficient $\left(\mathrm{Q}^{2} \mathrm{CV}\right)$ value of 0.892724 and the external validation $\left(\mathrm{R}^{2}\right.$ pred $)$ of 0.658537 . From the molecular docking studies carried out it was shown that all the ligands were binding with receptor (Lipase B) favourably. The applicability, stability and robustness of the generated QSAR model have been confirmed by internal and external validation assessment. The docking analysis indicated that the ligand 6, 7 and 18 with docking energy of $10.5,10.4$, and $10.3 \mathrm{kcal} / \mathrm{mole}$ are among the compounds with the highest docking scores. Ligand 6 being among the ligands with the highest binding affinity $(-10.5 \mathrm{k} / \mathrm{mole})$ was found to be more potent than its co-ligands. Stability and Robustness of the model highlight the way for designing latest Benzothiazinone-piperazine analogue with better activity against mycobacterium tuberculosis.

\section{R E F E R E N C E S}

$\begin{array}{crr}\text { WORLD HEALTH } & \text { ORGANISATION } & \text { (WHO). Global } \\ \text { Tuberculosis } & \text { Report } & 2015 .\end{array}$ http://www.who.int/tb/publications/global_report/en/ , 2015

WORLD HEALTH ORGANISATION (WHO). Global Tuberculosis Report $2018 . \quad$ http:// www.who.int/tb/publications/global_report/en/, 2018

LAMICHHANE, G.; FREUNDLICH, J.S.; EKINS, S.; WICKRAMARATNE, N.; NOLAN, S.T.; \& BISHAI, W.R. Essential metabolites of Mycobacterium tuberculosis and their mimics. Molecular Biology. 10 (1) 2011.

WORLD HEALTH ORGANIZATION. Multidrug and Extensively Drug resistant TB (M/XDR-TB) Global Report on Surveillance and Response, Press Release, 2010.

PRAKASH, P.; ARUNA, B.; SARDESAI, A.A.; \& HASNAIN, S.E. Purified recombinant hypothetical protein coded by open reading frame Rv1885c of Mycobacterium tuberculosis exhibits a monofunctional aroq class of periplasmic chorismate mutaseactivity: Journal of Biological Chemistry, 280, 19641-8, 2005.
SHOLA, E.A; SANI, U.; ADAMU, U. Geometrical and topological descriptors for activities modelling of some potent inhibitors against mycobacterium tuberculosis. Egyption journal of Chemistry 62(7), 1235-1247, 2019.

ABDULFATAI, U.; UZAIRU, A.; UBA, S. Quantitative Structure-Activity Relationship And Molecular Docking Studies Of A Series Of Quinazolinonyl Analogues As Inhibitors Of Gamma Amino Butyric Acid Aminotransferase. Journal of advance Research, 8, 33-43, 2017.

SHOLA, E.A.; SANI, U.; UZAIRU, A. Quantitative Structure -Activity Relationship And Molecular Docking Of 4-Alkoxy-Cinnamic Analogues As AntiTuberculosis. Journal of King Saud universityscience, $1-8,2018$. https://doi.org/10.1016/j.jksus.2018.02.005

MANOJ, C.; JANUPALLY, R.; JONNALAGADDA, P.S.; GANESH, S.P.; VANAPARTHI, A.; PERUMAL, Y; \& DHARMARAJAN, S. Benzothiazinone-Piperazine Derivatives As Efficient Mycobacterium Tuberculosis DNA Gyrase Inhibitors. International journal of mycobacteriology, 4, 104-115, 2015.

BECKE, A.D. "Becke's Three Parameter Hybrid Method Using The LYP Correlation Functional." The Journal of Chemical Physics, 98, 5648-5652, 1993.

YAP, C.W. Padel-Descriptor: An Open Source Software To Calculate Molecular DescriptorsAnd Fingerprints. Journal of Computational. Chemistry, 32, 1466-1474, 2011.

MUHAMMAD, T.I.; ADAMU, U.; GIDEON, A.S.; \& ABDULQADIR, I. In-Silico Studies Of Some Oxadiazoles Derivatives As Anti-Diabetic Compounds. Journal of King Saud University of Science, $1-10, \quad 2018$. doi.org/10.1016/j.jksus.2018.06.006

TROPSHA, A.; GRAMATICA, P.; GOMBAR, V.K. "The Importance Of Being Earnest: Validation Is The Absolute Essential For Successful Application And Interpretation Of QSPR Models." Molecular Informatics, 22, 69-77, 2003.

TROTT, O.; OLSON, A.J. Autodock Vina: Improving The Speed And Accuracy Of Docking With A New Scoring Function, Efficient Optimization, And Multithreading. Journal of Computational Chemistry, $31,455-461,2010$.

TODESCHINI, R.; CONSONNI, V.; GRAMATICA, P. Chemometrics in QSAR. Comprehensive chemometrics. ChemBiochem data anal, 4, 129-172, 2009. 


\section{APENDIX}

Table 1- Compounds structure and their activities

S/N Compounds

pIC50

1<smiles>[1H]c1ccc(NC(=O)N2CCN(c3nc(=O)c4cc([N+](=O)[O-])ccc4s3)CC2)cc1</smiles><smiles>O=C(Nc1ccc(Cl)cc1)N1CCN(c2nc(=O)c3cc([N+](=O)[O-])ccc3s2)CC1</smiles>

3<smiles>Cc1ccc(NC(=O)N2CCN(c3nc(=O)c4cc([N+](=O)[O-])ccc4s3)CC2)cc1</smiles>

4<smiles>O=C(Nc1ccc([N+](=O)[O-])cc1)N1CCN(c2nc(=O)c3cc([N+](=O)[O-])ccc3s2)CC1</smiles> 
<smiles>[1H]c1ccc(NC(=O)N2CCN(c3nc(=O)c4cc(C(F)(F)F)ccc4s3)CC2)cc1</smiles><smiles>O=C(Nc1ccc(Cl)cc1)N1CCN(c2nc(=O)c3cc(C(F)(F)F)ccc3s2)CC1</smiles><smiles>Cc1ccc(NC(=O)N2CCN(c3nc(=O)c4cc(C(F)(F)F)ccc4s3)CC2)cc1</smiles><smiles>O=C(Nc1ccc([N+](=O)[O-])cc1)N1CCN(c2nc(=O)c3cc(C(F)(F)F)ccc3s2)CC1</smiles> 
<smiles>[1H]c1ccc(NC(=O)N2CCN(c3nc(=O)c4cc(Cl)ccc4s3)CC2)cc1</smiles>

10<smiles>O=C(Nc1ccc(Cl)cc1)N1CCN(c2nc(=O)c3cc(Cl)ccc3s2)CC1</smiles>

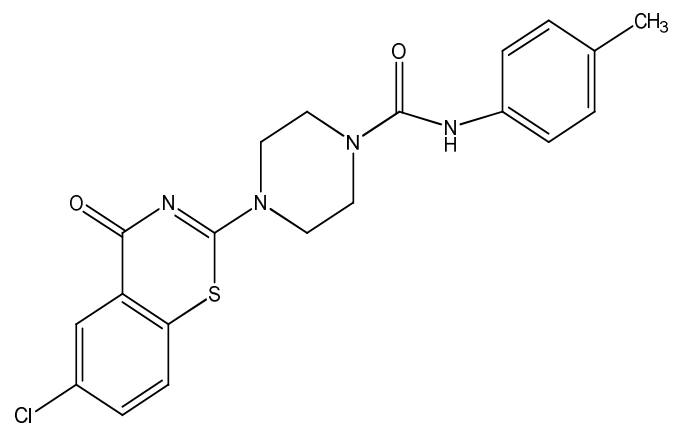

12<smiles>O=C(Nc1ccc([N+](=O)[O-])cc1)N1CCN(c2nc(=O)c3cc(Cl)ccc3s2)CC1</smiles> 
<smiles>O=c1nc(N2CCN(C(=S)Nc3ccc(Cl)cc3)CC2)sc2ccc([N+](=O)[O-])cc12</smiles><smiles>Cc1ccc(NC(=S)N2CCN(c3nc(=O)c4cc([N+](=O)[O-])ccc4s3)CC2)cc1</smiles>

16<smiles>O=c1nc(N2CCN(C(=S)Nc3ccc([N+](=O)[O-])cc3)CC2)sc2ccc([N+](=O)[O-])cc12</smiles>

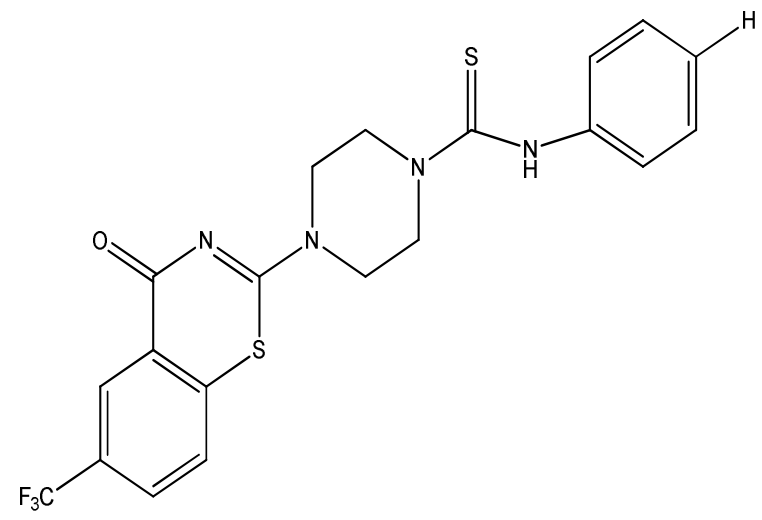




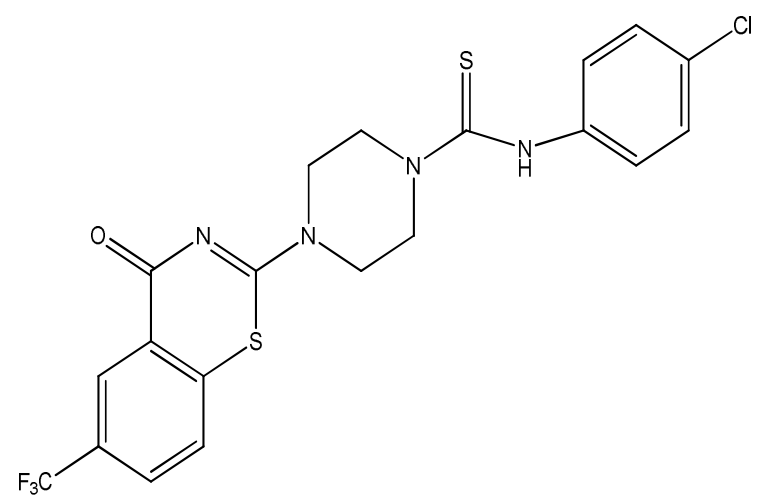

19<smiles>Cc1ccc(NC(=S)N2CCN(c3nc(=O)c4cc(C(F)(F)F)ccc4s3)CC2)cc1</smiles>

20<smiles>O=c1nc(N2CCN(C(=S)Nc3ccc([N+](=O)[O-])cc3)CC2)sc2ccc(C(F)(F)F)cc12</smiles>

21<smiles>O=c1nc(N2CCN(C(=S)Nc3ccc(I)cc3)CC2)sc2ccc(Cl)cc12</smiles>

22<smiles>O=c1nc(N2CCN(C(=S)Nc3ccc(Cl)cc3)CC2)sc2ccc(Cl)cc12</smiles> 
<smiles>Cc1ccc(NC(=S)N2CCN(c3nc(=O)c4cc(Cl)ccc4s3)CC2)cc1</smiles>

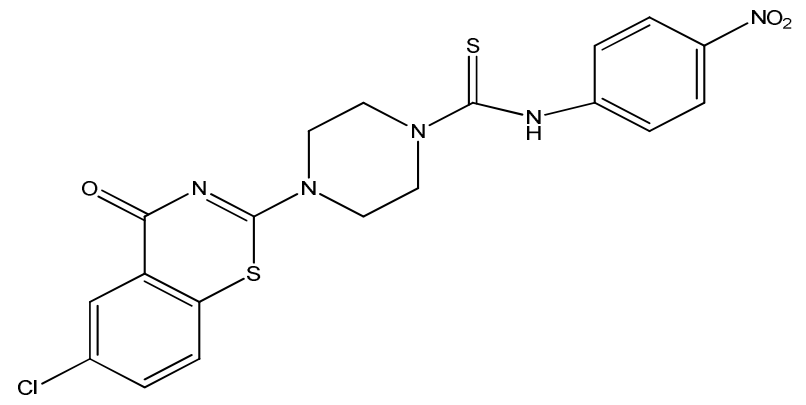

25<smiles>O=c1nc(N2CCN(Cc3ccc([O+])cc3)CC2)sc2ccc([N+](=O)[O-])cc12</smiles>

26<smiles>O=c1nc(N2CCN(Cc3ccc(Cl)cc3)CC2)sc2ccc([N+](=O)[O-])cc12</smiles>

27<smiles>O=c1nc(N2CCN(Cc3ccc([N+](=O)[O-])cc3)CC2)sc2ccc([N+](=O)[O-])cc12</smiles> 
<smiles>O=c1nc(N2CCN(Cc3ccccc3)CC2)sc2ccc(C(F)(F)F)cc12</smiles>

29<smiles>O=c1nc(N2CCN(Cc3ccc(Cl)cc3)CC2)sc2ccc(C(F)(F)F)cc12</smiles>

30<smiles>Cc1ccc(CN2CCN(c3nc(=O)c4cc(C(F)(F)F)ccc4s3)CC2)cc1</smiles>

31<smiles>O=c1nc(N2CCN(Cc3ccc([N+](=O)[O-])cc3)CC2)sc2ccc(C(F)(F)F)cc12</smiles>

32<smiles>O=c1nc(N2CCN(Cc3ccccc3)CC2)sc2ccc(Cl)cc12</smiles> 


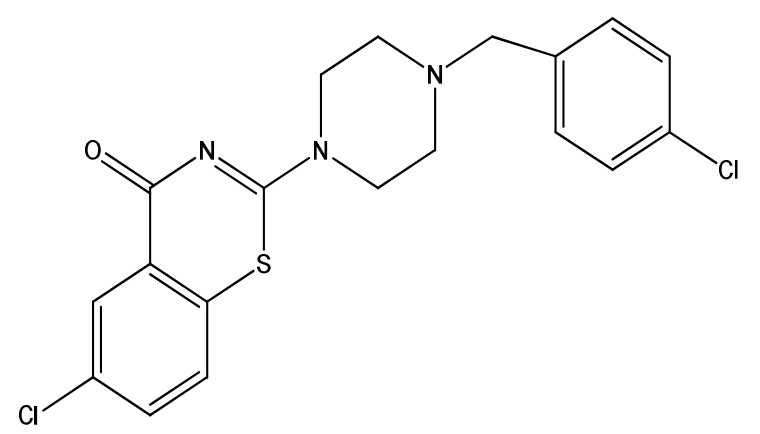

34<smiles>Cc1ccc(CN2CCN(c3nc(=O)c4cc(Cl)ccc4s3)CC2)cc1</smiles>

35<smiles>O=c1nc(N2CCN(Cc3ccc([N+](=O)[O-])cc3)CC2)sc2ccc(Cl)cc12</smiles>

Where superscript $t$ represent the test set 